\title{
The Evolution of Evolutionary Thinking in Chile
}

\author{
Rodrigo Medel
}

Published online: 29 May 2008

(C) Springer Science + Business Media, LLC 2008

\begin{abstract}
The scientific study of evolution in Chile has experienced periods of diversification and stasis, depending upon the social and political context at different times. In the eighteenth century, most of the natural history research consisted of systematics and taxonomy and, as in most of South America, this task was performed mainly by natural historian theologists. Later, the immigration of European scientists to Chile after independence from Spain in 1810 improved substantially its knowledge of the local biota and stimulated the diversification of naturalists in the country. Research in modern biology and the teaching of genetics in Chile can be traced back to Giovanni Noe, an Italian zoologist who had a profound impact in the first third of the twentieth century. In the 1960s-70s, Danko Brncic, a population geneticist educated in the tradition of Dobzhansky and the modern synthesis, led the most important diversification process in the study of evolutionary biology in the country. However, the military coup in 1973 brought this radiation to a sudden stop and produced a stasis period associated with the subsequent 17 -year dictatorship. Evolutionary biology recovered its status after the re-establishment of democracy, and it is currently experiencing an exciting and renewed diversification period that has led to the foundation of the Chilean Society of Evolutionary Biology, the only scientific society for the study of evolution in Latin America. One of the missions of the Society is to bridge the gap between scientists and science educators in order to improve the teaching of evolution at different levels both in secular
\end{abstract}

\footnotetext{
R. Medel $(\varangle)$

Departamento de Ciencias Ecológicas, Facultad de Ciencias, Universidad de Chile,

Casilla 653,

Santiago, Chile

e-mail: rmedel@uchile.cl
}

and religious schools. Even though the Roman Catholic Church has been a pivotal institution in the development of Chilean society, debate on evolutionism-creationism issues has been largely absent both in public and academic discussions. The influence of religion on science education has been sporadic, and mostly related to omission rather than tergiversation of scientific information in biology textbooks. Currently, schools are obliged by law to teach the basics of evolution in K-12 and K-16 levels (or their local equivalents). Because of this, there is little at present that suggests an organized creationist or intelligent design movement surge in the near future. Nevertheless, the high percentage of religiosity in Chile, together with the observation that the moral values of Chilean society are among the most conservative in the world, provide good reasons to remain vigilant.

Keywords Evolution · Chile · Creationism · Intelligent design $\cdot$ Religion

\section{Historical Remarks}

When Charles Darwin visited Chile in 1832-1835, 22 years after the formal independence of Chile from Spain, he probably did not imagine the role his observations in this country would have for the further elaboration of his theory of evolution by natural selection. In addition to the peculiar flora, fauna, and fossils he observed and collected, it was the rugged landscape shaped by volcanic and tectonic activities that caught the attention of Darwin and reinforced his idea of a world in continuous change (Darwin 1846; Moorehead 1969). Naturalists were not rare in Chile at that time, as indicated by Darwin himself in a letter to Henslow in October 28, 1834 "I had hoped during this time to have 
made a good collection of insects but it has been impossible. I regret the less, because Chili fairly swarms with collectors; there are more naturalists in the country than carpenters or shoemakers or any other honest trade." His observation was correct; several collections of different taxa already existed, particularly one initiated 80 years before by the abbot Juan Ignacio Molina. The abbot was a Jesuit intellectual who in 1768, at the age of 28 was exiled to Italy as a consequence of the expulsion of the Jesuit order from Chile, which was ordered by King Carlos III of Spain. In Italy, Molina published several works on the Chilean biota, which were translated into German, English, and French. Remarkably, some of his works were truly precursors of modern evolutionary theory since they represented one of the first attempts to organize nature into a coherent theory of gradual evolution, comparable only to the advances made by his contemporary Jean Baptiste Lamarck, 44 years before Darwin. According to Molina, God created nature as a continuous chain of organization, without abrupt changes between forms. In his view, minerals gave rise to the most basic forms of plants, more complex plants gave rise to simple animals, and simple animals produced more complex animals in a gradual progression.

In Chile, the Real Universidad de San Felipe, created in 1759 by instruction of Felipe V de Borbón, was almost the only cultural center in the country at that time, albeit largely devoted to theological and philosophical teaching. After the independence from Spain in 1810, a period of political instability followed, and a series of profound transformations and a fusion of institutions occurred. One of the most significant was the foundation in 1839 of the Universidad de Chile, which replaced the Real Universidad de San Felipe. Unlike the previous institution, the new one was rooted in the cultural and educational values of the emerging republican society and was inspired by illustrious European philosophers and intellectuals such as Rousseau, Locke, Kant, and Voltaire, among others. The new republican society required a detailed catalogue of the Chilean territory as part of the so called "expansion age," characterized by the settlement of colonies in the southernmost region of the country. As in most universities, the advancement of different areas of knowledge was one of the missions of the recently founded Universidad de Chile, which provided an interesting academic environment for several European naturalists who found their place in Chile. Natural history and its two major contributing disciplines, zoology and botany, began to develop according to European models (Cruz-Coke 2004). Many naturalists and intellectuals arrived in Chile at that time, and most of the still valid classifications of the Chilean biota may be attributed to the magnificent contributions of the French botanist and naturalist Claude Gay (1800-1873), with whom Darwin interacted during his stay in Chile (Yudilevich and Castro 1996), and the German biologist Rudolf Philippi (1808-1904) (see reviews in Mizón 2001; Castro et al. 2006).

From the mid-nineteenth to early twentieth century the development of science was in close relationship to the consolidation of the new nation. The arrival of French, German, and British naturalists in Chile had a profound impact in schools and universities. The German naturalist Frederic Johow (1859-1933) was a pioneer in promoting the teaching of evolutionary biology in Chilean education. While the beginnings of the twentieth century found Chile with a relatively well-known fauna and flora, it was necessary to improve scientific capacity both in universities and educational centers. The school of medicine of the Universidad de Chile was the locus of most of the incipient research done at that time in the country, and the interest of the government in improving the quality of medicine resulted in the hiring of the Italian physician Giovanni Noé in 1912 (1876-1946), who was Professor of Medical Zoology at the University of Rome. As a disciple of the Italian zoologist Giovanni Grassi, he was involved in the description of the life cycle of Plasmodium. Noé had a profound impact on his students. In fact, he was responsible for teaching zoology, morphology, and genetics at the level of European countries. Although his contribution to Chilean biology has not been adequately recognized, Noé paved the way for the first generation of geneticists in Chile.

After the Second World War, the development of biology and medicine in Chile almost invariably followed AngloSaxon models (Cruz-Coke 2004). The exciting advances in evolutionary biology articulated in the modern synthesis were propagated in Chile thanks to the visit of Dr. Theodosius Dobzhansky in 1956. Dobzhansky's stay had a strong influence on a young student who was probably the most influential scientist in the history of evolutionary biology in Chile. Danko Brncic (1922-1998) spent some time in Dobzhansky's lab at Columbia University, where he had first-hand contact with the several questions and approaches to study of ecological genetics in Drosophila. The geographical isolation of Chile from the rest of South America provided a suitable biogeographical setting to develop a research program on Chilean Drosophila. Guided by Dobzhansky, Brncic was actively involved in the development of the synthetic theory of evolution and became a leader of the research in population genetics not only in Chile but in South America as a whole. After his return to Chile, there was an explosion of research in genetics (basic and applied), natural history, experimental evolution, and population biology, in what may be called the first radiation of evolutionary biology in the country. In the 1960 's, there was a relatively mature and diversified 
community involved in genetic research, which led to the foundation of the Chilean Society of Genetics in 1964. One of the missions of the emerging society was to promote the advance and teaching of genetics at the undergraduate and graduate levels. This effort had a tremendous impact on the development of the discipline across Chilean universities. However, the rapid diversification was suddenly interrupted as a consequence of the military coup in 1973. Pinochet's dictatorship attempted to disintegrate Chilean universities, especially the Universidad de Chile, and prohibited any meetings or associations, including scientific societies, in the first years of the dictatorship (Litvak 1983). Hundreds of outstanding scientists were relieved of their positions, emigrated outside the country, or were exiled. Geneticists were not the exception. The stasis period had arrived.

When democracy was re-established in 1990, after 17 years of military dictatorship, teaching and research in genetics and evolutionary biology had not changed substantially in either scope or depth, partly due to the political isolation of Chile, which restricted the chance of academic and student exchange with foreign countries. The development of evolutionary biology in Chile during that period was kept constant at best. With only a couple of exceptions, the few courses on evolution available emphasized nonscientific topics that provided fertile ground for epistemological discussions but not for scientific research. More specifically, by questioning not only the prevalence but the entire existence of natural selection as a force driving evolutionary change, a peculiar all-inclusive perspective elaborated in the 1970s gained adherents in young and uninformed undergraduate students (see Maturana-Romesín and Mpodozis 2000). Although this doctrine stimulated an interesting debate among Chilean naturalists (e.g., Gallardo 1997; Camus 2000; Nespolo 2003), it had a strong detrimental impact on several cohorts of students, ultimately retarding the advance of evolutionary biology research in Chile. Fortunately, the situation has changed in the last few years as an increasing number of students are involved in scientific research on a diverse array of evolutionary questions. At the undergraduate level, modern evolution is taught both in secular and religious universities. At least one course of evolution and/or genetics is present in $84 \%$ of the biologically oriented scientific careers (e.g., marine biology, environmental biology, bachelor of biological sciences) and $73 \%$ of the biologically based education careers (P. Camus, personal communication). An inverse interpretation of these figures indicates that about $15 \%$ of science programs and $25 \%$ of education programs in Chilean universities are not teaching evolution, which deserves special attention and demands improvement.

Regarding disciplinary development, and noting that research in evolutionary biology is still in its infancy in Chile, the most represented areas are evolutionary ecology, population and quantitative genetics, systematic biology, and biogeography. Areas less represented include genomics-bioinformatics, molecular evolution, and paleobiology. The areas still absent include experimental evolution and evo-devo (R. Nespolo, personal communication). This thematic diversity has provided a renewed atmosphere among Chilean naturalists, which has stimulated the recent foundation of the Chilean Society of Evolutionary Biology, the only scientific society for the study of evolution in Latin America. One of the missions of the Society is to bridge the gap between scientists and educators in order to improve the teaching of evolution at different education levels.

\section{The Teaching of Evolution and the Creationist Menace}

The education system in Chile is currently divided into three levels, (a) a preschool level, with children under the age of five; (b) a basic school level, that includes eight grades with a typical age ranging between 5-12 years; and (c) a high school level that includes four grades with ages ranging 13-17. A national standardized college placement test is given annually; the scores obtained by students on this test and high school grade averages determine their chances of being enrolled in one or another university and program.

The teaching of evolution in Chile has experienced advances and retreats through history. The importance given to evolution in high school textbooks seems to be the outcome of the balance between the antagonistic and often irreconcilable positions of secular intellectuals and conservative Catholic ideology. For example, while biological evolution was included as an important topic in the official education program in 1902, many of the biology textbooks used during the twentieth century were written by Catholic priests, some of them clearly antievolutionists. As expected, topics on evolution were largely dismissed or relegated to small commentaries on "evolutionism and religion" (see details in Tamayo 2003). This unfortunate influence lasted many years and found its climax in the period 1969-1984, when topics on evolution were virtually eliminated from textbooks, probably as a consequence of the pressures imposed by conservative religious and political groups (Tamayo 2003). The situation changed drastically in 1991, when evolutionary content had to be included in the new curriculum by law. Since then, an important section devoted to phenotypic and genetic variation, mechanisms of selection, and patterns of evolution has been included in most textbooks, and the teaching of evolution is obligatory at present.

Chilean scientists have been traditionally involved in the elaboration of science curricula in basic and high school 
levels. For instance, the current curriculum in evolutionary biology is the outcome of a long process that involves the joint participation of scientists and teachers. After several rounds of personal and public consulting and improvement, curricula are finally written and promulgated in the form of law statements by the Congress. The structure of curricula involves two components. First, a general component, that deals with contents that must be taught by every school in the country (e.g., the basics of genetics, development, variability, natural selection, heredity, and adaptation). Second, a more specialized component that is taught in the last 2 years of the high school level (e.g., the origin of life, patterns of biological diversification, theories and mechanisms involved in human evolution, analysis of genetic information, and methodology of scientific research in biology). There is a complete exclusion of creationist and ID arguments in Chilean curricula of evolutionary biology. In synthesis, the basics of evolutionary biology seem to be adequately covered in Chilean education at present, although there is ample scope to improve the quantity and quality of education in the basic and high school curricula. Scientists and teachers, however, do not only collaborate in curricula design. An interesting and fruitful initiative aimed to increase collaboration between scientists and teachers has been led by CONICYT (the Chilean equivalent of NSF) in the last 10 years. This program consists of transferring science to basic and high school levels in the form of talks, visits of students to Universities, and the collaborative action of scientists and teachers in the design and implementation of research activities for basic and high school students. There is ample opportunity to improve the knowledge of biology and evolutionary biology in schools under this government initiative.

The level of religiosity in Chile is high, as revealed by the observation that $92 \%$ of the Chilean population older than 15 years profess some religion or credo; $70 \%$ of the population are Catholic; $15.1 \%$ Protestant or Evangelical; $8 \%$ atheist or agnostic; $4 \%$, other religion or credo; $1 \%$ Jehova 's witnesses; $0.9 \%$, The Church of Jesus Christ of Latter-day Saints; $0.1 \%$ Jewish; and less than $0.1 \%$ Islamic and Eastern Orthodox (source: National Census data 2002, http://www.ine.cl/cd2002). These figures are consistent with the report of the International Social Survey Programme in 1998 (Lehman 2002). A multivariate index representing the level of religiosity of 31 countries all over the world was constructed and compared among countries. Interestingly, the level of religiosity of the Chilean population was one of the highest of the sample, only surpassed by the Philippines, USA, and Cyprus. Not surprisingly, a high percentage of the Chilean population believes in God (96\%), the existence of miracles $(81 \%)$, and even witchcraft (60\%) (Adimark-CfK 2007). However, the high level of religiosity shown by the Chilean population is inconsistent with the low frequency of periodic attendance in religious ceremonies $(21 \%)$ (Adimark-CfK 2007), which suggests an ideological rather than practical commitment to religion. Regarding moral issues, the Chilean population is one of the most conservative in the world (Lehman 2002), which in combination with the high level of religiosity, provides an appropriate target for creationist or intelligent design movements. In fact, small ephemeral foci of creationism appear from time to time, but always restricted to churches and conservative education centers outside the mainstream of Chilean education. Even though Chilean society has been long modelled by the interaction of Republican ideals and the strong influence of the Roman Catholic Church, issues around the evolutionism-creationism dichotomy are largely absent both in public and academic discussions. As in the rest of South America, there is little at present that suggests an organized creationist movement surge in Chile in the short run (Cornish-Bowden and Cárdenas 2007). However, this does not imply that Chilean science is immune. Because the crusade of creationism and its multiple faces is not circumscribed to geographic region, culture, or language, it is better to be prepared and vigilant. Probably the most efficient way to avoid a creationist intrusion into our educational system and society is to improve basic understanding of the evolutionary process not only in basic and high school levels, but in the Chilean population as a whole. The Chilean Society of Evolutionary Biology is currently devising the best strategy to accomplish this task.

Acknowledgments I thank Niles Eldredge and John Thompson for inviting me to write this manuscript. I also thank Carezza Botto, Patricio Camus, Lafayette Eaton, Roberto Nespolo, Manuel Tamayo, and Alberto Veloso for commenting on various stages of this paper and for kindly providing useful information that improved the quality of this essay. This paper was partially supported by grant ACT 34/ 2006.

\section{References}

Adimark-GfK. Encuesta Nacional Bicentenario UC Adimark. 2007.

Camus PA. Evolution in Chile: natural drift versus natural selection, or the preservation of favoured theories in the struggle for knowledge. Rev Chil Hist Nat. 2000;73:215-9.

Castro SA, Camousseight A, Muñoz-Schick M, Jaksic FM. Rodulfo Amando Philippi, el naturalista de mayor aporte al conocimiento taxonómico de la diversidad biológica de Chile. Rev Chil Hist Nat. 2006;79:133-43.

Cornish-Bowden A, Cárdenas ML. The threat from creationism to the rational teaching of biology. Biol Res. 2007;40:113-22.

Cruz-Coke R. Organization of genetic services: Chile. In: Wertz DC, Fletcher JC, editors. Genetics and ethics in global perspective. Dordrecht: Kluwer Academic; 2004.

Darwin C. Geological observations on South America. Cornhill: Smith Elder \& Co; 1846. 
Gallardo M. Determinismo estructural: "teoría o dogma". Rev Chil Hist Nat. 1997;70:315-9.

Lehman C. "Cuán religiosos somos los chilenos": mapa de la religiosidad en 31 países. Estudios Públicos 2002;85:21-40.

Litvak S. Survival and revival: Chilean universities under Pinochet. Nature 1983;306:11-2.

Maturana-Romesín H, Mpodozis J. The origin of species by means of natural drift. Rev Chil Hist Nat. 2000;73:261-310.

Mizón L. Claudio Gay y la formación de la identidad cultural chilena. Santiago de Chile: Editorial Universitaria; 2001.
Moorehead A. Darwin and the Beagle. New York: Harper \& Row; 1969.

Nespolo RF. Evolution by natural selection: more evidence than ever before. Rev Chil Hist Nat 2003;76:699-716.

Tamayo M. Evolución de las teorías biológicas evolutivas en libros de texto de enseñanza en Chile. PhD Thesis 2003, Universidad de Granada, España.

Yudilevich D, Castro E. Darwin en Chile (1932-1935): viaje de un naturalista alrededor del mundo. Santiago de Chile: Editorial Universitaria; 1996. 